\title{
Merging opposing viewpoints: Analysis of the development of a statewide sustainable local food advisory council in a traditional agricultural state
}

\author{
Molly De Marco,a,b* Leah Chapman, ${ }^{\mathrm{a}, \mathrm{b}}$ Cordon McGee, ${ }^{\mathrm{a}}$ Larissa Calancie, ${ }^{\mathrm{c}}$ \\ Lauren Burnham, and Alice Ammerman a,b \\ University of North Carolina at Chapel Hill
}

Submitted May 2, 2017 / Revised May 17 and June 16, 2017 / Accepted June 22, 2017 /

Published online September 5, 2017

Citation: De Marco, M., Chapman, L., McGee, C., Calancie, L., Burnham, L., \& Ammerman, A. (2017).

Merging opposing viewpoints: Analysis of the development of a statewide sustainable local food

advisory council in a traditional agricultural state. Journal of Agriculture, Food Systems, and Community

Development, 7(3), 197-210. http://dx.doi.org/10.5304/jafscd.2017.073.018

Copyright (C) 2017 by New Leaf Associates, Inc.

\begin{abstract}
Food policy councils (FPCs) are a useful way for interested groups to work together to create
\end{abstract}

${ }^{a}$ Center for Health Promotion \& Disease Prevention, University of North Carolina at Chapel Hill; 1700 Martin Luther King, Jr. Blvd., CB\# 7426; Chapel Hill, NC 275997426 USA.

${ }^{b}$ Department of Nutrition, Gillings School of Global Public Health, University of North Carolina at Chapel Hill; 135 Dauer Drive; 245 Rosenau Hall, CB \#7461; Chapel Hill, NC 27599-7461 USA.

c Center for Health Equity Research, School of Medicine, University of North Carolina at Chapel Hill; 323 MacNider Hall, CB\# 7240; 333 South Columbia Street, Chapel Hill, NC 27599-7240 USA.

* Corresponding author: Molly De Marco, Center for Health Promotion and Disease Prevention, University of North Carolina at Chapel Hill; 1700 Martin Luther King, Jr. Blvd.; Chapel Hill, NC 27599-7426 USA; molly_demarco@unc.edu mutually beneficial change within the food system. Often formed through grassroots organizing or commissioned by governmental entities, FPCs have been successful at tackling challenges within food systems by creating forums to address issues whose roots ordinarily are in disparate parts of these systems. Little peer-reviewed research exists, however, examining the formation of state-level FPCs, particularly among states known for their conventional production practices. In this case study, we explored the process of forming a statewide FPC in North Carolina from 2007 to 2009. The objectives were to (a) qualitatively examine the two-year process of forming a statewide FPC in a traditional agriculture state, and (b) identify the factors that led to its formation. To do so, we developed an in-depth interview guide for interviewing eight individuals, including government stakeholders, conventional agricultural producers, 
sustainable agricultural producers, philanthropists, and legal representatives. We used qualitative analysis methods to analyze the transcripts, drawing on John Kingdon's agenda-setting and policyformation theory to guide analysis. Results indicated that four factors drove the formation of the North Carolina state-level FPC: (1) stakeholder involvement, (2) diverse partnerships, (3) stakeholder ability to compromise, and (4) a conducive political setting. While the small sample size prevents us from causally interpreting our results and generalizing our findings, this preliminary research may provide insight for other states, especially those with a predominately traditional agriculture system, that are interested in forming state-level FPCs.

\section{Keywords}

State Food Policy Council; Case Study; North Carolina; Policy; Food System

\section{Introduction}

According to the Agriculture Sustainability Institute at the University of California, Davis, a food system is typically defined by five major components: production, processing, distribution, consumption, and waste management (Sustainable Agriculture Research and Education Program, n.d.). The U.S. food system has evolved significantly over the last 100 years, such that its components contribute severely to obesity, environmental degradation, and economic and health disparities (Drewnowski \& Darmon, 2005; Drewnowski \& Specter, 2004; Lakdawalla \& Philipson, 2002; Wackernagel et al., 2002). The food system depends heavily on fossil fuels for production, processing, and distribution, which adversely affects the environment, concentrates wealth in the hands of a few large producers and multinational organizations, and contributes to farmland loss, particularly by farmers of color (Hinson \& Robinson, 2008; Lobao \& Meyer, 2001; Solomon et al., 2007). Nevertheless, many argue that conventional agriculture production supported by synthetic chemicals (pesticides and fertilizers) is the only way to meet burgeoning domestic and global food needs (Connor, 2012; Seufert, Ramankutty, \& Foley, 2012). Food system stakeholders often have diverse and conflicting interests, which makes it difficult to identify simple solutions to these food systems problems. Food policy councils (FPCs) are one way for interested groups to work together to create change within the food system that mutually benefits all parties (Harper, Shattuck, HoltGiménez, Alkon, \& Lambrick, 2009). FPCs can also help draw attention to grassroots initiatives to improve local food systems and can act as a voice for these issues and concerns by recommending policies to local, state, and federal government (Borron, 2003; McCabe, 2010).

An FPC consists of representatives and stakeholders from various sectors of the food system (Harper et al., 2009). They typically include antihunger and food justice advocates, educators, members of nonprofit organizations, concerned citizens, government officials, farmers, grocers, chefs, workers, food processors, and food distributors (Harper et al., 2009). "Councils range from informal groups without a steering committee to more formal groups with a chair and executive committees. Those more formal groups sometimes included several subcommittees, or 'task forces' that specialize in researching and make recommendations on certain topics" (Harper et al., 2009, p. 27). Harper and colleagues (2009) found three main ways that FPC members are chosen: selfselection; application (reviewed by the exiting council, an executive board, or the initiating community members); and election, nomination, or appointment (chosen by governmental officials or an executive board). There are FPCs serving rural areas and tribal communities, as well as advising on food policy issues at the state and regional level.

The goal of FPCs is to bring diverse stakeholders together, identify and develop solutions to problems within the local food system, and offer recommendations for policy change (Harper et al., 2009). FPCs are often formed through grassroots organizing, but can also be commissioned by governmental entities (Harper et al., 2009). The first FPC in the U.S. started in Knoxville, Tennessee, in 1982 to help those struggling to meet food needs after aid program cutbacks, and to improve food equity, supply, and cost (Knoxville-Knox County Food Policy Council, n.d.). The number of FPCs in the U.S. and Canada rose sharply from 1990 to 
2009 (Harper et al., 2009). The growth continues: the Community Food Security Coalition directory listed 92 FPCs in the U.S., Canada, and the Tribal Nations as of 2010 (Scherb, Palmer, Frattaroli, \& Pollack, 2012). By 2015 the Food Policy Network project at Johns Hopkins University listed 282 FPCs in the U.S., Canada, and Tribal Nations (Food Policy Network, 2015a). Few of these are state-level FPCs, however: 32 percent of councils operate at the county or district level, 22 percent operate at the city or municipality level, 19 percent operate regionally, 13 percent influence counties and cities together, just 12 percent influence states or provinces, and two percent operate within tribes (Food Policy Network, 2015b).

There has been little peer-reviewed research examining food policy councils, and even less that has examined state-level organizations. A 2012 case study by John Cotton Dean explored the "challenges and opportunities" experienced by the Iowa state-level FPC, noting that it carried out a number of activities such as promoting local foods, streamlining the state's food stamps application process, and submitting food and agricultural policy recommendations to the governor (Dean, 2012). While these activities may have strengthened the food system, they were only described qualitatively by study participants. There is no evidence that the policy recommendations presented to the governor were ever implemented (Dean, 2012). Further, no outcomes such as a change in the food insecurity rate or an increase in food stamp utilization were measured to examine the impact of food policy council activities on the food system (Dean, 2012). A 2012 national survey of 56 FPCs by Scherb et al. found that 85 percent were engaged in policy activities at the time of the survey (Scherb et al., 2012). The authors stated that "few" FPCs mentioned evaluating their policy work, however, and they called for more rigorous evaluation efforts of FPC processes, impacts, and outcomes (Scherb et al., 2012). A 2015 qualitative study by Coplen and Cuneo noted that the Portland Multnomah Food Policy Council (PMFPC) in Portland, Oregon, had several achievements, including a healthy corner store initiative, a beginning farmer training program, and changes to zoning codes to expand urban agriculture. But this FPC was disbanded in
2012 due to its "waning relevancy," and no evaluation of its effects on the food system were measured (Coplen \& Cuneo, 2015, p. 102).

\section{Background}

North Carolina is home to a number of countyand municipal-level FPCs. North Carolina formerly had a statewide FPC, formed in 2001, which came together with the help of the Drake University Agriculture Law Center, which had received a grant from the USDA to help establish FPCs in key states. The North Carolina FPC was active through the life of the grant, but because it lacked stateimplemented legislation to mandate its existence as a state-sanctioned entity, it was disbanded at the end of the grant cycle in 2003. There was still interest among its members and others involved with the state food system in having a state FPC. The Center for Environmental Farming Systems (CEFS), a partnership between North Carolina State University, North Carolina Agricultural and Technical State University, and the North Carolina Department of Agriculture and Consumer Services, revived the idea of a statewide FPC in 2008.

As part of a more comprehensive initiative to develop a strategic action plan for building North Carolina's local food economy, CEFS led a series of statewide and regional meetings and listening sessions with interested individuals (Curtis, Creamer, \& Thraves, 2010). Working Interest Teams (WITs) were formed around a variety of food-related issues, including a team that discussed forming a council. Members of this WIT drafted policy language and sent it to their legislators in various regions of the state. One member of the North Carolina House and one of the North Carolina Senate had already considered such legislation and instructed staff to draft the initial legislation for a statewide food policy council based on the draft language provided by the WIT. They then attracted co-sponsors. The bill passed the House but was subsequently pulled from legislative consideration because certain stakeholder parties had not been engaged adequately in the development process. The bill was sent to a subcommittee, whose members referred it back to the stakeholder group to discuss. The subcommittee worked with the stakeholder group to modify the language of 
the bill to be more representative of all viewpoints. The bill was returned to the Senate, and in August 2009 the bill to create the North Carolina Sustainable Local Food Advisory Council was passed. The sustainable agriculture groups involved in the establishment of the council wanted the word "sustainable" in the title as it depicted the food system that they envisioned. Conventional agriculture representatives were able to accept inclusion of the word because the bill used the USDA definition of sustainable from the 1990s (Farm Bill, 1990), with which they felt comfortable.

The council, officially coined the Sustainable Local Food Advisory Council, was established in August 2009. The membership fluctuated, but there were between 24 and 27 members (Figure 1), based on suggestions by stakeholder organizations and appointed by one of four state officials: the commissioner of agriculture, the speaker of the house, the pro tempore, and the governor.

The council met monthly and established three subcommittees: Health, Wellness, Hunger, and Food Access; Economic Development and Infrastructure; and Land, People, and Natural Resources. These subcommittees and, in turn, the council focused on issues such as the availability of quality crop insurance products, zoning and extraterritorial jurisdictions, the use of SNAP (formerly known as food stamps) and WIC benefits at farmers markets to help low-income North

\section{Figure 1. Sustainable Local Food Advisory} Council Representation

- Sustainable farming

- Conventional farming

- State Commissioner of Agriculture

- State Health Director

- Commercial fishing

- Grange

- Farm Bureau

- 3 University (sea grant, agriculture, public health)

- Legal profession

- Nongovernmental organizations

- Department of Public Instruction

- State Office of Extension

- Food bank

- Food service and/or retail

- Land Conservation

- Economic Development

- Processing
Carolinians to access healthy foods, development of policies for the use of school garden produce in cafeterias, and Whole Farm GAP (Good Agricultural Practices) certification.

In 2012, the sunset date of the council was extended to July 31, 2017, from the original 2012 date. During 2012, the council began to seek additional funding from federal and private sources due to statewide budget cuts. But following a shift in state political party power, not only was a Republican governor elected to replace the Democratic governor, but the legislature came under Republican control for the first time in 200 years. The council was eliminated as of July 2013 per State Law 2013-360, Section 13.4. Ironically, the WIT had decided on legislative action to establish the council to protect against being eliminated at the whim of a single governor's executive order; nevertheless, it was still eliminated easily through legislative action with the change in leadership.

After the elimination of the council, 12 of the organizations that had representation on the NC Sustainable Local Food Advisory Council continued to meet, including representatives of government, universities, Extension, farm bureau, and nonprofits. Representatives from these organizations are working to reformulate a council. Keeping in mind the lessons learned during their time as the council, the group is determining how to structure a new council and what its role in the state will be. The new state-level FPC in North Carolina is striving to achieve a balance between freedom and ties to government to affect policy change that supports local food systems across the state, while sustaining itself as an independent entity.

Some research exists concerning FPC activities (Harper et al., 2009; Scherb et al., 2012; Walsh, Taggart, Freedman, Trapl, \& Borawski, 2015), but the efforts that go into forming a food policy council at the state level require more elucidation. This is particularly true for states with a strong conventional agriculture presence such as North Carolina (the leading producer of hogs in the nation), as more conflicts between invested stakeholders may arise when forming a FPC. There may be lessons for states and municipalities interested in state-level food policy councils, especially those that have 
both strong conventional and strong sustainable agriculture systems.

For this exploratory case study, we examined the realities of forming a statewide food policy council, a relatively new development as there are currently only eight statewide FPCs, in a state dominated by conventional agriculture production, through interviews with a diverse group of stakeholders. The objectives were to investigate qualitatively the two-year process of formation (2007 to 2009) and to identify the factors that ultimately led to the creation of a statewide FPC. We used John W. Kingdon's model of agenda setting theory and policy formation to guide our analysis and place our findings in the context of the literature on policy change and network development. Kingdon states that political change happens when three "streams" come together: problem recognition, policies, and politics (1995). Problem recognition means that a particular problem has been brought to attention, and that there is a general consensus that the problem needs to be addressed. The second stream, policies, refers to an actual policy in place, which could solve the problem. Politics signifies that a political climate is open and receptive to change. All three streams of Kingdon's model were satisfied at the time of council formation, allowing for political change to occur.

\section{Methods}

\section{Sampling Strategy and Recruitment}

We identified potential interview participants using a purposive sampling frame. We chose participants based on suggestions from key informants who were known to the authors and were heavily engaged in the creation of the legislation, because those involved in the process of council formation were not publically known. From this pool, we selected and invited people for interviews based on their level of participation in developing and implementing the legislation, with further advice from CEFS staff. All potential participants were contacted and informed of the purpose of the interview and asked if they were still willing to participate. If the participant agreed to be interviewed, an appointment was scheduled to conduct the interview via telephone. All eight participants invited to participate completed interviews. To maintain confidentiality, we refrain from using names throughout this paper.

\section{Procedures}

Using a structured interview guide, we conducted interviews with a diverse group of eight participants who were key players in the formation of the food council. These participants represented a conventional farming organization, conventional livestock production, a sustainable agriculture organization, food safety advocacy, state agencies, a philanthropic organization, and the legal field. The University of North Carolina at Chapel Hill Institutional Review Board approved the study. Prior to each interview, each participant was told the purpose of the study and that participation was voluntary, was asked for permission to audio-record the interview, and was provided an explanation that the recording and transcript would be kept confidential. The interviews lasted between 45 to 60 minutes. Interviews were conducted until we began to hear the same information from respondents; we stopped adding new interviewees at eight participants. All interviews were conducted via telephone and audio-recorded. Recordings were transcribed verbatim.

\section{Interview Guide}

The interview guide consisted of 20 questions about the process of developing the statewide FPC. Questions were primarily open-ended and included follow-up probes. We included questions about the background of the participant in the food system; political, social, economic, and organizational conditions surrounding the policymaking process; interested parties and their involvement; influence of interested parties; stakes held by interested parties; success of strategies; timelines; and significance for future policymaking. Sample questions included "How was the decision made about what people or organizations should be at the table during this process?"; "What means did [name of organization] use at these points to influence the policy-making process?"; and "In what ways was [name of organization] effective in getting the Food Policy Council legislation passed?" 
Data Analysis

We analyzed the interview transcripts using content analysis (Berg \& Lune, 2014). We developed a codebook of themes and subthemes based on the questions of interest, the questions asked during the interview, and any themes that emerged during an initial review of the transcripts. Two research staff coded each of the transcripts within Microsoft Word, then met to review the coding of each transcript and reconcile any differences (Willging, Waitzkin, \& Nicdao, 2008). Research staff then reviewed the themes and subthemes to determine which were most salient. Those themes and subthemes found to be most relevant to our research objectives were summarized, looking for agreement and disagreement among participants.

\section{Results}

Preliminary results from this exploratory qualitative study indicated that four factors led to the formation of the North Carolina statewide FPC: stakeholder involvement, diverse partnerships, stakeholder ability to compromise, and conducive political setting. We used John Kingdon's model of agenda setting theory and policy formation to help interpret our interview data. Results are divided into four subsections, each examining a different factor that led to council formation.

\section{Factor 1: Stakeholder Involvement}

Stakeholder involvement was one theme that arose from our qualitative data analysis. It considers how strong leadership from key stakeholders was vital to council formation and examines their reasons for involvement with the North Carolina state FPC, as well as benefits and drawbacks of their participation.

Strong Leadership. The effort to build the council was spearheaded by a horticulture professor from a state university that specialized in sustainable agricultural practices, who brought together stakeholders to shape the legislation for the state FPC and employed a communications consultant to facilitate the process. Individuals at the university had the initial idea to write a funding proposal to work on developing a sustainable, local food economy in North Carolina and were the lead organizers of this process.
Two other strong key leaders in the formation of the council were individuals from a sustainable agriculture organization and a statewide foundation. The sustainable agriculture organization representative chaired the Foundations and Baselines WIT and provided leadership for rebirth of an FPC as the game-changing idea from the WIT. Having a vast amount of experience in both sustainable food systems development and food assessment, he was able to lead the WIT in developing the idea. The statewide foundation representative was very knowledgeable in policy-making and contributed his expertise to the WIT, helping to mediate as needed. The foundation eventually provided a grant to the NC Department of Agriculture and Consumer Services to support the initial operations of the FPC.

Study participants described the engagement of strong stakeholders who led negotiations and encouraged compromise. A participant from conventional animal production also applauded the work of the professor who led the council formation effort:

Dr. $[\mathrm{X}]$ has worked so hard and has gotten so much grant money and has really done such good work for my university... and for the agriculture community and you have to want to support somebody that is so passionate about what they believe in.

With many varying opinions among stakeholders, it was important to make sure that productive conversation continued and that the legislative process kept moving forward, despite debate and disagreement. A representative from the farmer advocacy organization described the actions of a fellow stakeholder whose leadership skills were praised by several interviewees:

...He was extremely diplomatic, and at one point in a meeting, he just sort of looked at everybody and said, "What's it going to take to make this happen?”

Stakeholders appreciated his determination to produce "something powerful," along with his knowledge and expertise in policy-making. 
The strong leadership of stakeholders who were involved was also described by three stakeholders as crucial to building momentum and excitement behind the FPC legislation, as well as to developing support for the idea prior to the initiation of the legislative process. A participant representing the legal profession emphasized this point:

...Before [the initiating organization] announced any sort of legislative effort, they created an infrastructure for understanding what it would be about and communicating about it. So... they sort of organized a network of supporters before there was a piece of legislation and so the legislation sort of grew into that.

A remark from the representative of the farmer advocacy organization highlights the importance of strong leadership to the development of a FPC, especially one with statewide reach:

Whenever you have people doing things that they're not accustomed to- that might be out of the ordinary - it makes them uncomfortable. So not just anybody is going to be a driver in this; you have to have the right personalities involved and a lot of people with diplomacy.

Motivations for Involvement. It is important to highlight what specifically motivated the involvement of stakeholders. The reason most often cited by study participants was to help bring together knowledgeable people from all sectors of food and agriculture to make progressive change. Others cited that they wanted to help North Carolina farmers make more money and diversify their markets, to build the North Carolina economy, and to promote the local food movement at the state level. Others became involved because working on policy regarding a state FPC was within the scope of their organization's mission. Two participants went a step further, saying they had hoped the council would further a specific interest of their organization, such as sustainable farming or urban gardening. Participants felt inspired to share personal expertise in areas such as public policy, community outreach, and FPCs. Many stakeholder organizations contributed their own resources toward passage of the legislation, primarily staff time spent tracking the legislation, staff travel, attending meetings, reviewing the language in the bill, and providing feedback.

Another motivator discussed by study participants was benefits to their organizations, or to the agricultural community and to the public. One main benefit reported was attention that the council could bring to the local and sustainable food movement. Developing new partnerships among members of the FPC was another important benefit discussed. Anticipated partnerships included conventional agriculture and nontraditional agriculture working together, and linking consumer and producer representatives. Four participants mentioned projected benefits for their organizations, such as networking, increased business once the issues received more attention, increased ability to fundraise, and using council resources. Multiple participants discussed potential benefits for farmers and the people of North Carolina, including improvements in the economy, improvements in health, and development of new markets for farmers.

Drawbacks to Involvement. While there were many benefits to participating in council formation that helped stakeholders to persevere, there were drawbacks as well. For example, the representatives of stakeholder organizations faced some anger and backlash from those they represented who were against formation of such a council. A representative from a conventional growers group put it this way: "There were people on my side of the table, for lack of a better term, that were...unwavering, not willing to compromise, were not having it, were not hearing it, and didn't want to do anything to help."

\section{Factor 2: Diverse Partnerships}

Diverse partnerships contributed to the formation of the council, through increased sharing of ideas among council formation stakeholders, as well as increased ability to reach target audiences when advertising and rallying support for the council. Political and conventional agriculture partnerships may be the most important of all partnerships in 
the formation of a state FPC in a state dominated by conventional production practices. We conclude this section with a caveat: although diverse partnerships were important in council formation, participants cautioned against "having too many people at the table."

Individuals representing diverse sectors such as higher education, nonprofits, conventional and sustainable agriculture, and the political and legal systems contributed to the development of the FPC. The North Carolina Department of Agriculture (NCDA) was also a key player in forming the council. According to a study participant who was a sustainable agriculture advocacy group representative, NCDA representatives "spoke a lot in some of the committee meetings that we went to in support of the bill, representing the Department of Agriculture because there were a lot of questions like, 'We've got the "Got to be NC" program, why do we need this council?' So talking about why it was important for the Department of Agriculture to participate in this. So, they were also pretty influential." Another important figure in developing the legislation was a former gubernatorial aide who was able to help the stakeholders navigate the legislative process. He checked in with both legislators and other stakeholders and helped keep the process moving. Participants applauded these diverse partnerships. A representative from the state Department of Agriculture stated:

I think most of us who were involved and who got involved realized that it was important to have, quote, "all" of agriculture and food stakeholders, a wide range...I think these kind of things, to be successful, you have to have a broad range, a diverse group of folks to come together and, frankly, that becomes part of the challenge.

Another interview participant explained:

Dr. $[\mathrm{X}]$ really did an amazing job trying to pull together all kinds of people to make up the working groups [WITs], she really did. And I think that worked well. Everything that she did leading up to the introduction of the legislation was excellent; there was momentum behind it, there was a lot of idea sharing.

These diverse partnerships influenced the process of forming the FPC by spreading the word about benefits of a FPC to their colleagues. Many members, in turn, advocated for their state legislators to vote in favor of the legislation:

One organization that has a lot of membership of sustainable growers...they got the word out to their membership about this, and I know that there were growers who communicated with their elected officials [about the benefits of a state FPC].

Importance of Political and Conventional Agriculture Partnerships. Partnerships involving representatives from conventional agriculture may be particularly important in forming a statewide FPC, especially in a state such as North Carolina where the conventional agriculture industry has a major presence. Many stakeholders gave the conventional animal production participant credit for not derailing the process. A participant, who was a representative from a farmer agency, explained it this way:

The group that was the lynchpin group in getting the bill passed was [conventional animal producer trade organization]. And I want to tell you why: because if they had gotten spooked, if they were not willing to go and allow this to happen, then the other aspects of conventional ag, we would have had to say, "Look, folks, we can't do this."

The leaders from the conventional agricultural sector realized that they needed to be a productive part of FPC formation, or else the bill would not serve their interests. As the representative from a conventional animal production organization said:

I think we need a seat at the table, but the purpose is not to dilute what they want, it's to be part of it. I said [to my constituents], "They're going to figure out a way to do it, 
and you might hate worse what happens if you don't allow me some room."

In addition to partnerships with conventional agriculture producers, political partnerships may also be particularly important for forming a statewide FPC. Members of the North Carolina General Assembly were particularly influential, cosponsoring the bill in the State House and Senate and remaining supportive throughout the process. State legislators also played important roles: House and Senate sponsors and their staffs were responsible for drafting the legislation. One participant from an environmental nonprofit described one state representative's motivation for passing the bill:

[He] has got a lot of sustainable farmers in his district, and he wants to grow that industry. He heard about this idea at a conference that he went to in the mountains and loved it and right from the get-go was like, "I'm going to make this happen, ya know, I want to do something positive for sustainable ag." So, he was going to make sure that something good came out of this in the end.

A different participant from the conventional animal production organization pointed out that key policy-makers were also helpful in a more tangible way:

There's something, sadly, there's something about an elected official being in the room or at the table that forces people to consider the other viewpoints, not just stand strong in their own stance, not just plant their feet down and not move. Because somebody has to be there to sort of massage it along.

It is important to mention one caveat. Although participants described the importance of diverse partnerships in council formation, they also cautioned about having too many people involved. One mentioned that drafting the legislation took longer because "so many people were at the table." As one sustainable agriculture representative described: "I really thought there was going to be more opportunity for meaningful input, but there really wasn't. It was a much...there were, I don't know, sixty people on this advisory committee, and you just can't [get meaningful input from everyone with those numbers]." At the beginning, many participants had concerns about the large number of people engaged in the process of developing the legislation, and that it would unnecessarily prolong the process. Some were worried that those against the creation of a statewide FPC could stall the process by continually bringing up more concerns. This did not occur, however.

\section{Factor 3: Stakeholders' Ability to Compromise}

This subsection discusses two areas of compromise that arose in the formation of the council: compromise to draft legislation and compromise on council composition.

Compromise to Draft Legislation. Significant legislation-drafting issues included the process of drafting the policy, the question of who would have a say in the specific wording, the location of council meetings, and how the bill would be shepherded through the state legislature.

Key stakeholders discussed specific pieces of the legislation prior to the drafting. Most group members, however, only saw the post-drafting finished product. At that point, members were given the opportunity to provide comment and decide with their constituents whether to support the legislation and work to garner membership support for the bill. After the original draft was released, several negotiation meetings were held. The representative from the sustainable agriculture advocacy group noted that these negotiations "did not happen in the Senate or House Committee meetings. They happened with these interest groups that then brought bills back to [legislative] representatives. It was all a really big learning process for me. Like, 'Oh, we do it [negotiate on the language of the bill]? Wow."

The final draft of the legislation needed editing to accommodate the interests of the diverse stakeholders. In particular, the definitions of "sustainable" and "local" needed to be agreed upon. At one point, one of the conventional agriculture groups asked that the word sustainable be removed from 
the legislation. Other stakeholders, however, felt that removal of the word sustainable from the legislation would change the nature of the council and thus the purpose of the bill. Organizations had different opinions of how local should be defined. Some thought that the definition should include all food grown in North Carolina, but others questioned how meaningful that would be considering the size of the state and the proximity of other states. The representative from a conventional agriculture organization made the point that if North Carolina taxes were spent on council recommendations, then local would have to be defined for geopolitical reasons as grown or produced within North Carolina. The conventional animal production organization was particularly concerned that the definition would result in precluding less sustainable methods of animal production, while other groups thought local should also imply sustainable. The representative from the sustainable agriculture organization elaborated on the complexity of the issue:

If you're in some eastern counties, CAFOs [concentrated animal feeding operations] are local agriculture, so now you have to make another definition on top of it and ask, "Are they sustainable?" and "How do you define that?" and "How does that work with the food access issues and the affordability of food?" There's just a whole other Pandora's box of issues that are going to have to be dealt with.

However, after much discussion, a compromise was made to use the USDA definition of sustainable (Farm Bill, 1990):

"The term sustainable agriculture means an integrated system of plant and animal production practices having a site-specific application that will, over the long term:

- satisfy human food and fiber needs;

- enhance environmental quality and the natural resource base upon which the agricultural economy depends;

- make the most efficient use of non- renewable resources and on-farm resources and integrate, where appropriate, natural biological cycles and controls;

- sustain the economic viability of farm operations; and

- enhance the quality of life for farmers and society as a whole."

After these negotiations, the word sustainable was allowed to stay in the bill. Similarly, the group members ultimately decided that local would indicate foods from the state of North Carolina.

\section{Compromise on Council Composition.}

There were also many concerns about who would hold a seat on the council, how many seats there would be, who would appoint individuals to fill these seats, the proportion and type of farmers included, which groups would be represented, and whether stakeholder organizations would continue to be represented. The sustainable agriculture organizations and farmers that introduced the bill, not anticipating the high level of interest of the more traditional groups, had already negotiated among themselves to determine a list of those who would sit on the council. A compromise was made to pare this list back and better include the traditional agriculture groups. The representative from the conventional animal production organization explained, however, that their intention was not to dominate the council, but be a part of it:

I mean some of my people wanted it to be all farmers, nothing but farmers, half sustainable and half conventional, but that doesn't work. I think we need a seat at the table, but the purpose is not to dilute what they want, it's to be part of it.

This representative expressed concern that several organizations that his organization felt "had extremist views" and had "slandered traditional agriculture on the Internet" were on the initial council member list. After the final list was made, two interviewees still thought that it included too many seats to be productive. Overall, however, the stakeholders reached a consensus. 
Factor 4: A Conducive Political Setting

A conducive political setting for legislation passage of the state FPC was highly important. There was no requirement for state funding attached to the bill for the council; if it had been part of the bill, political representatives may not have supported the bill. Worth noting, however, is that while the political setting at the time was conducive, the subsequent change in political climate-election of a Republican governor-made elimination of the council possible.

The North Carolina state FPC was created at a time when the political, economic, and social atmosphere were supportive. Three participants mentioned this political window of opportunity, discussing how the House sponsor was already interested in the issue and how the Senate sponsor, a powerful figure in agriculture, was also on board to support the council. Both legislators represented farming districts, and their influence aided greatly in passing the bill and creating the council. A representative from an environmental safety nonprofit further explained the critical timing of this bill:

I think the timing was really good for the issue. [It was] something that a lot of people had been hearing something about, and I think a lot of legislators had been hearing something about it and wanting to know, "What could benefit my district?" and "What can I do for this?" and "It's something in my district that people care about." And it's not a high conflict sort of thing. It's not the kind of thing that's going to take something away from somebody else. It's not going to add a new burden of regulation to anyone, so it had those kinds of things going for it.

Economically, the idea for the North Carolina state FPC was developed at an ideal time. The director of a state-level foundation stated that his organization had an initiative that year to support local food activities, with funding set aside for that purpose. As the FPC aligned with the goals of that initiative, the foundation could fund it. Four other participants spoke of the economic opportunity associated with the sustainable and local food movements, and that they are among the sectors of agriculture currently showing growth. They also discussed the economic challenges the state was facing, with more people beginning to farm either out of necessity or opportunity.

Five stakeholders also discussed increased public interest in local and sustainable food. The FPC was created when these issues were becoming important to consumers. The representative from the sustainable agriculture organization described this interest:

I think local foods has transformed from a kind of, how do you say, a niche, to kind of, ya know, it's not just a granola thing eaten by people in Chapel Hill, Carrboro, or whatever, it's more of a part of the arsenal of the agricultural industry, food industry in North Carolina.

Another study participant mentioned that North Carolina has many resources and strong players because of the large academic and health care presence in the state, noting that this contributed to the creation of the FPC as well.

One noteworthy caveat is that there was no state funding allocated along with the bill for the council. This may have helped garner political support and ease passage because there was no direct financial impact on the state budget. A representative from a farmer advocacy agency stated that the State Department of Agriculture "was willing to take it [the council] as long as it did not force them to spend extra money because they didn't want to have to be committed to spending, ya know, two or three or four hundred thousand dollars on something out of their very, very tight budget that was being slashed."

\section{Discussion}

This exploratory qualitative case study found that four factors ultimately drove the formation of the 2009 North Carolina state FPC: stakeholder involvement, diverse partnerships, stakeholder ability to compromise, and a conducive political setting. It is important to note that although the council was established through legislative action in August 2009, North Carolina's political leadership 
changed in 2013, and the council was eliminated as of July 2013 per State Law 2013-360, Section 13.4. Thus one of the factors that allowed for the council's creation — the political setting —also led to its elimination. An important lesson for other states interested in state-level FPCs would be to strategize tactics that protect councils from elimination through legislative action due to a changing political climate.

Our results are consistent with a 2012 case study by Dean regarding the Iowa state-level FPC. Although the primary aim of that study was to explore the challenges and opportunities faced by the Iowa FPC, it was determined that diverse partnerships and strong leadership were factors in the creation of the Iowa FPC (Dean, 2012). To the best of our knowledge, no other studies have explored the factors that lead to the creation of a state-level FPC.

We have used John Kingdon's model of agenda setting theory and policy formation to guide our analysis and place our findings in the context of the literature on policy change and network development. According to Kingdon, political change happens when three "streams" come together: problem recognition, policies, and politics. Problem recognition means that a particular problem has been brought to attention, and that there is a general consensus that the problem needs to be addressed. In the case of the North Carolina FPC, a general consensus existed that local food issues needed addressing, as demonstrated by the activity of CEFS and the WITs. This satisfies the first stream of Kingdon's model. The second stream, policies, refers to an actual policy in place which could solve the problem. The policy must be technically feasible and compatible with the values of the population. There were already functioning state-level FPCs in other states, such as the Iowa Food Policy Council; thus this stream is also present. The stream of politics means that the political climate is open and receptive to change. This final stream was clearly present, as one of the four factors that led to the formation of the state FPC was a conducive political setting. With the three streams of Kingdon's model satisfied at the time of council formation, political change could occur. The formation of the state FPC shows a engagement of policy process theory with practice, and our study is consistent with the literature on agenda setting and policy formation.

Strengths of this study include diverse representation among study participants. In addition, to the best of our knowledge this is the first peerreviewed study to explore factors that contributed to the creation of a state-level FPC. This study has several limitations, however. Above all, the sample size of eight individuals does not allow us to generalize to a larger population or to interpret our results causally. In addition, this study used a purposive sampling strategy, so researchers relied on their own judgment when choosing members of the population to participate in the study, which may have influenced the study results. Our research is therefore exploratory, not conclusive. We do believe that our findings are instructive for and illustrative of the issues other states with industrial agriculture sectors would encounter during FPC formation.

\section{Conclusion}

Although the North Carolina state FPC dissolved in 2012, understanding the factors that led to council formation may be helpful for other states and municipalities considering a state-level food policy council. Our research is exploratory, however; future research should further examine the challenges and opportunities of FPCs, using larger sample sizes and testing for reliability and validity using strategies such as triangulation and member and document validation.

\section{Acknowledgements}

We would like to thank Laura Joseph, Lauren Short, and Stephane Cox for assistance with qualitative analysis. We would also like to thank Robin Crowder, Suzanne Havala Hobbs, and Nancy Creamer for assistance with development of the interview guide and for review of drafts of the manuscript. 


\section{References}

Berg, B. L., \& Lune, H. (2014). An introduction to content analysis. In B. L. Berg \& H. Lune (Eds.), Qualitative research methods for the social sciences (8th ed.) (pp. 335-372). Harlow, UK: Pearson.

Borron, S. M. (2003). Food policy councils: Practice and possibility. Eugene, Oregon: Congressional Hunger Center. Retrieved from http://www.foodpolicynetworks.org/food-policy-resources/?resource $=118$

Burgan, M., \& Winne, M. (2012). Doing food policy councils right: A guide to development and action. Santa Fe, New Mexico: Mark Winne Associates. Retrieved from http://www.markwinne.com/wp-content/uploads/2012/09/FPCmanual.pdf

Connor, D. J. (2012). Organically grown crops do not a cropping system make and nor can organic agriculture nearly feed the world. Field Crops Research, 144, 145-147. http://dx.doi.org/10.1016/j.fcr.2012.12.013

Coplen, A., \& Cuneo, M. (2015). Dissolved: Lessons learned from the Portland Multnomah Food Policy Council. Journal of Agriculture, Food Systems, and Community Development, 5(2), 91-107. http://dx.doi.org/10.5304/jafscd.2015.052.002

Curtis, J., Creamer, N., \& Thraves, T. E. (2010). From farm to fork: A guide to building North Carolina's sustainable local food Economy (Report). Raleigh, North Carolina: Center for Environmental Farming Systems. Retrieved from https://cefs.ncsu.edu/resources/from-farm-to-fork-a-guide-to-building-north-carolinas-sustainable-local-foodeconomy-2010/

Dean, J. C. (2012). The Iowa Food Policy Council: A case study (master's thesis). Retrieved from Graduate Theses and Dissertations (No. 12827). http://lib.dr.iastate.edu/etd/12827

Drewnowski, A., \& Darmon, N. (2005). The economics of obesity: Dietary energy density and energy cost. American Journal of Clinical Nutrition, 82(1 Suppl.), 265S-273S. Retrieved from http://ajcn.nutrition.org/content/82/1/265S.full?sid=a7953e29-4017-411d-849f-62403acf3ff6

Drewnowski, A., \& Specter, S. E. (2004). Poverty and obesity: The role of energy density and energy costs. American Journal of Clinical Nutrition, 79(1), 6-16. Retrieved from http://ajcn.nutrition.org/content/79/1/6.full? sid=cc5a0a06$\underline{5 b 1 b-401 c-a 91 a-e e 8 c c 819 d 3 a 8}$

Farm Bill. (1990). Definitions. Title XVI (Research), Subtitle A, Section 1603 (Definitions). Washington, D.C.: Government Printing Office. Retrieved from https://www.nal.usda.gov/afsic/sustainable-agriculture-definitionsand-terms \#toc2

Food Policy Network. (2015a). Food policy council directory. Baltimore, Maryland: Johns Hopkins Center for a Livable Future. Retrieved from http://www.jhsph.edu/research/centers-and-institutes/johns-hopkins-center-for-a-livablefuture/projects/FPN/directory/online/

Food Policy Network. (2015b). Food policy councils in North America: 2015 trends (PowerPoint presentation). Baltimore, Maryland: Johns Hopkins Center for a Livable Future. Retrieved from https://assets.jhsph.edu/clf/mod clfResource/doc/FPC Trends Slides 201510 28.pdf

Harper, A., Shattuck, A., Holt-Giménez, E., Alkon, A., \& Lambrick, F. (2009). Food policy councils: Lessons learned (Development Report No. 21). Oakland, California: Food First Institute for Food and Development Policy. Retrieved from https://foodfirst.org/publication/food-policy-councils-lessons-learned/

Hinson, W. R., \& Robinson, E. (2008). "We didn't get nothing": The plight of Black farmers. Journal of African American Studies, 12(3), 283-302. http://dx.doi.org/10.1007/s12111-008-9046-5

Kingdon, J. W. (1995). Agendas, alternatives, and public policies (2nd ed.). New York: HarperCollins College.

Knoxville-Knox County Food Policy Council. (n.d.) About us. Knoxville, Tennessee: Author. Retrieved from http://www.knoxfood.org/

Lakdawalla, D., \& Philipson, T. (2002). The growth of obesity and technological change. Economics and Human Biology, 7(3), 283-293. https://doi.org/10.1016/j.ehb.2009.08.001

Lobao, L., \& Meyer, K. (2001). The great agricultural transition: Crisis, change, and social consequences of twentieth century US farming. Annual Review of Sociology, 27, 103-124. http://dx.doi.org/10.1146/annurev.soc.27.1.103

McCabe, M. S. (2010). Reconsidering Federalism and the farm: Toward including local, state, and regional voices in America's food system. Journal of Food Law \& Policy, 6(2), 151-165. Retrieved from http://heinonline.org/HOL/LandingPage?handle=hein.journals/ifool6\&div=11\&id=\&page 
Scherb, A., Palmer, A., Frattaroli, S., \& Pollack, K. (2012). Exploring food system policy: A survey of food policy councils in the United States. Journal of Agriculture, Food Systems, and Community Development, 2(4), 1-12. http://dx.doi.org/10.5304/jafscd.2012.024.007

Schiff, R. (2008). The role of food policy councils in developing sustainable food systems. Journal of Hunger \& Environmental Nutrition, 3(2-3), 206-228. http://dx.doi.org/10.1080/19320240802244017

Seufert, V., Ramankutty, N., \& Foley, J. (2012). Comparing the yields of organic and conventional agriculture. Nature, 485(7397), 229-232. http://dx.doi.org/10.1038/nature11069

Solomon, S., Qin, D., Manning, M., Chen, Z., Marquis, M., Averyt, K. B.,...Miller, H. L. (2007). Climate change 2007: The physical science basis. Contribution of working group I to the fourth assessment report of the IPCC (Vol. 4). Cambridge, UK \& New York: Cambridge University Press.

Sustainable Agriculture Research and Education Program. (n.d.). Defining sustainable community food systems. Davis, California: U.C. Davis Agricultural Sustainability Institute. Retrieved from http://asi.ucdavis.edu/programs/sarep/research-initiatives/fs/sfs/defining-sustainable-community-food-systems

Wackernagel, M., Schulz, N. B., Deumling, D., Linares, A. C., Jenkins, M., Kapos, V.,...Randers, J. (2002). Tracking the ecological overshoot of the human economy. Proceedings of the National Academy of Sciences, 99(14), 9266-9271. http://dx.doi.org/10.1073/pnas.142033699

Walsh, C. C., Taggart, M., Freedman, D. A., Trapl, E. S., \& Borawski, E. A. (2015). The Cleveland-Cuyahoga County Food Policy Coalition: "We have evolved." Preventing Chronic Disease, 12(6), E86. http://dx.doi.org/10.5888/pcd12.140538

Willging, C. E., Waitzkin, H., \& Nicdao, E. (2008). Medicaid managed care for mental health services: The survival of safety net institutions in rural settings. Qualitative Health Research, 18(9), 1231-1246.

http://dx.doi.org/10.1177/1049732308321742 